\title{
Recycle or Dispose Off? Lifecycle Environmental Sustainability Assessment of Paint Recycling Process
}

\author{
Is rael Dunmade
}

Department of Environmnetal Science, Mount Royal University, Calgary, T3E 6K6, Canada

\begin{abstract}
People are sometimes confronted with the need to decide whether a product should be recycled or disposed off. The purpose of this project was to assess whether it is more environmentally sustainable to recycle paint than to dispose it off in a landfill or not. Lifecycle assessment method was used to analyze potential environmental costs and benefits associated with paint recycling. Data used for the analyses were collected from a recycled paint manufacturing company, literature, and a database. The lifecycle impact analyses of the paint recycling process were based on monthly production of a recycled latex paint brand. Results of the analyses revealed that the process have a monthly $122760.8 \mathrm{~kg}$ $\mathrm{CO}_{2}$-eq global warming potential (GWP), $1481.6 \mathrm{max} \mathrm{kg} \mathrm{O}$-eq eutrophication potential (EP), and $106.8 \mathrm{~kg} \mathrm{C}_{2} \mathrm{H}_{4}$-eq photochemical ozone creation potential (POCP). The LCA results showed an environmental benefit of eliminating $31,237.29 \mathrm{~kg} \mathrm{CO}_{2}$-eq GWP, 0.02kg CFC-1 leq Ozone depletion potential (ODP), 5943.58 $\mathrm{kg} \mathrm{C}_{2} \mathrm{H}_{4}$ eq POCP and $197.83 \mathrm{max}$ $\mathrm{kg} \mathrm{O}_{2}$ eq EP by recycling latex paint rather than disposing it off in the landfill and producing equal amount of latex paint to replace it . Results also revealed that recycling of paint containers and plastics reduces the GWP by $25.34 \%$, ODP by $29.79 \%$, POCP by $15.39 \%$, and EP by $12.47 \%$. Paint recycling is therefore not only economically wise but it is also ecologically sustainable.
\end{abstract}

Keywords Environmental Impacts, Environmental Cost, Environmental Benefit, Latex Paint, Life Cycle Assessment

\section{Introduction}

Water dilutable (latex) paints are widely used all over the world as a backdrop to the campaign against solvent emissions. They are used for surface protection, beautification and rejuvenation. Latex paints are applied in residential and commercial indoor environments. They are also used in the painting of car bodies[1].

About 30 million litres of paint is sold in A lberta, Canada every year. $5-10 \%$ of these paints and over 1 million empty paint containers are disposed off annually in Alberta[2]. Similarly, over 16 million gallons of latex paint (W LP) is also disposed off in USA every year[3]. However, increasing awareness of the potential environmental and health risks posed by residual paints necessitated regulation of waste paint disposal. Some of these paints contain combustible materials, volatile organic compounds, lead, mercury, and other heavy metals[4 -7]. Consequently, municipalities are required to collect residual paints from households for proper waste management. For example, waste paint constitutes around $21.7 \%$ of the total hazardous waste (HZW) collected by municipalities in Ontario

* Corresponding author:

idunmade@mtroyal.ca (Is rael Dunmade)

Published online at http://journal.sapub.org/re

Copyright (C) 2012 Scientific \& Academic Publishing. All Rights Reserved province every year. Waste latent paint alone constitutes $12 \%$ of the total HZW [8]. The good news about these waste paints is that many have potentials for reuse, recycling and recovery[9, 10]. Recyclability of waste paints is an indication that their human and environmental risks could be eliminated or minimized by recycling. The largeness of the amount of latex paint disposed annually indicated its high economic potential[11]. As a result of these potentials, a number of organizations are now involved in latex paint recycling. However, recycling of materials also has socio-economic and environmental implications. This necessitates an assessment of the net benefit (or cost) of recycling resources at the end of their useful lives[12]. This case study involved a number of forward looking individuals that sought and experimented how these old paints could be reprocessed, repackaged and reused for various applications. These individuals have been reprocessing and repackaging old paints for about ten years and they wanted to know the environmental worth of their paint recycling effort. They also want to know whether it is more environmentally sustainable to recycle latex paint than disposing it off in a landfill or not.

\section{Methodology}

Lifecycle Analysis (LCA) method was used for this study because it is a comprehensive and proven analytical tool for 
evaluating potential environmental burdens resulting from resource consumption and emissions by a product or process. It also enables us to assess product/process environmental impacts and to evaluate improvement opportunities that could be implemented to address areas of concerns [13-19]. The method consists of four iterative steps (Figure 1): goal and scope definition, inventory analysis, impact ass essment, and interpretation.

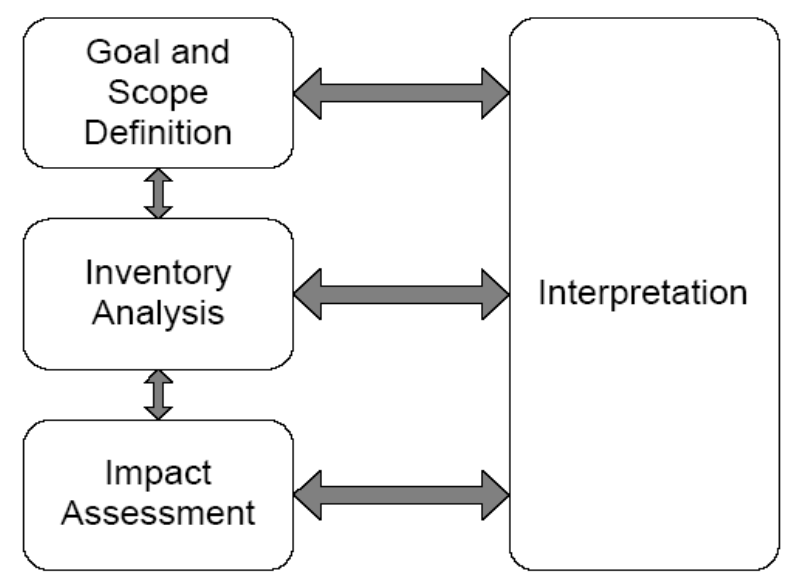

(Source: Eco-efficiency-action-project.com)

Figure 1. An illustration of LCA process

\subsection{Goal and Scope Definition}

The main purpose of this LCA study was to determine whether it is more environmentally sustainable to recycle latex paint than to dispose it off in a landfill. Other reasons for the project are:

- To evaluate the environmental burden associated with the monthly production of a recycled paint over their entire process lifecycle in order to identify the stage with the largest environmental impacts (hot spots)

- To identify impact category of greatest concern with the aim of finding ways of reducing the ecological footprint

\subsection{Functional Unit and System Boundaries}

The functional unit was defined as the mass of a monthly production of 12 colour recycled latex paint in two packages of 4, 10 and 18.9 litres. The company produces 60000 litres of recycled paint every month for sale to the clients. The monthly volume of recycled paint production is approximately $49,800 \mathrm{~kg}$ by mass.

The system boundaries for the analysis are shown in Figure 2. The entire lifecycle was composed of the following stages:

- Old paint transfer from municipalities to the company's recycling facility in Calgary

- Sorting and inspection of the paints to oil based paints, reusable latex paint, and unreusable latex paint

- Emptying of reusable latex paints into one of the 12 totes based on the paint colour

- Compression and transportation of metallic and plastic containers for recycling

- High speed mixing of each full tot of latex paint
- Filtration of the paints to remove particles and to comply with industry standard

- Storage tank mixing of the paints

- Packaging of the processed paints into 4, 10 and 18.9 litres containers

- Distribution of reprocessed latex paint to retailers

- Transportation of oil paints and unreusable latex paint for disposal in landfills

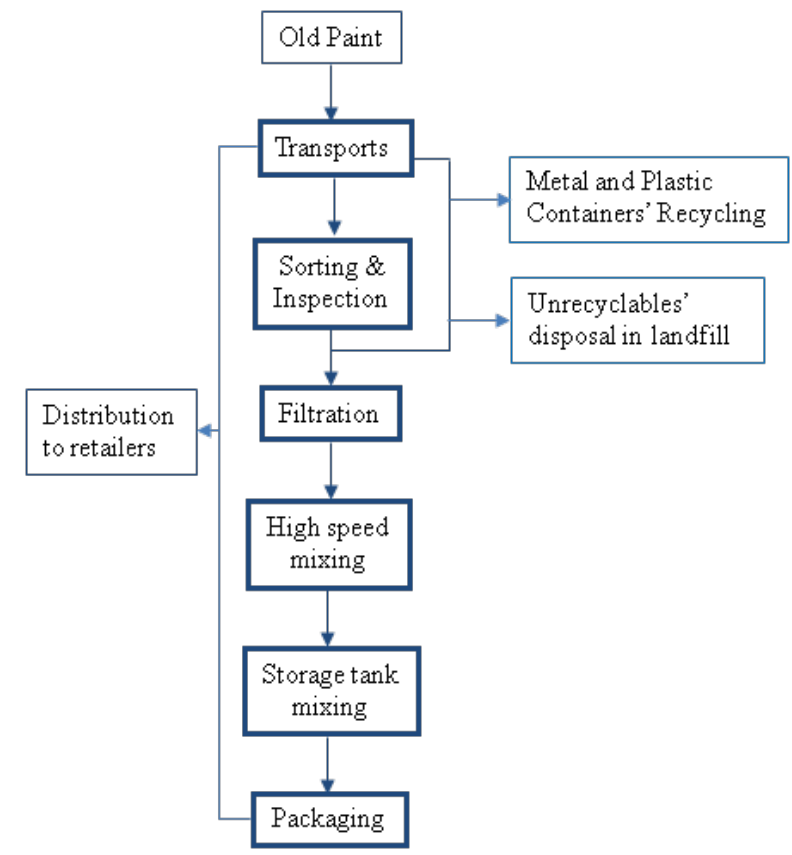

Figure 2. General flow scheme of paint recycling process

In addition to these main sequential processes, each stage of the process lifecycle included energy utilization. Allocation is not necessary in this case study because it is a single output process. In order to simplify the study, materials and emissions less than $0.01 \%$ of the functional unit were not included in the study. Production, maintenance and disposal of machinery and buildings as well as their environmental burdens were also excluded from the study. Non-material values, economic aspects, and human resources were also not considered.

Two dimensions of impact analyses were carried out: absolute impact analysis and comparative/relative impact analysis. The absolute impact analysis examined the potential environmental impacts of the recycled paint production on its own. The comparative analys is assessed the recycled paint production process in relation to avoided disposal and avoidance of the need to produce same amount of new virgin paint to replace the disposed old paint.

The comparative/relative impact analysis aspect of this study was based on the average composition, resource use and emissions from the various brands of residual latex paints used as input by the company.

Environmental impacts of packaging, distribution and disposal from the paint recycling process were excluded on the premise that new virgin paint production would require the same number and type of packaging. It was also 
reasoned that environmental impacts of distribution would be the same for the new virgin paints as well as for the recycled paint. This is because the company has the same client base. So, the impact would be the same if the company is to manufacture and/or distribute the same amount of new virgin paints that they are recycling. Furthermore, it was assumed that no other ingredient is added to the old paint materials in producing the recycled paint.

\subsection{Lifecycle Inventory}

Inventory data compilation was implemented by using database included in Simapro 7.2 software. Process specific data used for the analysis was collected from the paint recycling company. The primary data on material and energy use as well as solid waste emissions was collected from the company in 2011. Secondary data was obtained from literature and eco-invent database. Table 1 is a sample of inventory data for the paint recycling process. This conformed to the recommendation in [18].

\subsection{Impact Ass ess ment}

Five categories of impact were considered for each dimension of the two impact analyses. The impact categories are global warming potential (GWP), ozone depletion potential (ODP), photochemical ozone creation potential (POCP), acidification potential (AP), and eutrophication potential (EP). All the inventory data that could be found on the available conversion tables and that are greater or equal to $100 \mathrm{mg}$ were mapped into the affected impact categories. 100years time horizon conversion data were used for the characterization of inventory data for global warming and ozone depletion potentials. Conversion factors for average of three European countries were used for the POCP while maximum oxygen conversion data were used for eutrophication potential ass es sment.

\section{Results and Discussion}

This study was carried out to determine whether it is more environmentally sustainable to recycle latex paint than disposing it off in a landfill or not. Tables 3 and 4 showed the summary of lifecycle impact analyses of the inventory data collected for this task. Figure 3 showed the percentage contribution of each recycling process stage to individual impact category. Although there were LCA reports on paints, no report was found on LCA of latex paint recycling process that these results can be compared with[20, 21]. In addition, this study was not aim at process comparison. The following interpretation of the study results was based on
ISO 14043.

\subsection{Inter pre tation}

The standard (ISO 14043) stipulated a three step process for LCA results interpretation: (i) identification of environmentally significant issues from the inventory data and from the lifecycle impact assessment results, (ii) evaluation of those significant issues, and (iii) drawing conclusion from the evaluated significant is sues.

\subsubsection{Identification Of Significant Is sues}

In determining environmentally significant issues, Carbon dioxide was found to be the most significant substance emitted. From the impact as sessment table (table 2 ), it was discovered that global warming which causes climate change is the most significant environmental issue in the paint recycling process. The method and the data used for this study were evaluated and found to be consistent with the requirements of ISO 14040s.

\subsubsection{Evaluation}

Consistency and completeness of the LCA analysis steps taken were evaluated and they were found to be in conformity with the ISO 14043 standard. This was followed by evaluation of the contribution of each process stage to various impact categories. Figure 3 showed percentage contribution of each recycling process stage to various impact categories. One could see from table 3 that distribution stage of the process has an overwhelming influence on the total potential global warming impact of the process. Packaging is another stage of the recycling process that contributes most significantly to ozone depletion potential and photochemical ozone creation (i.e. photochemical smog) potential of the process.

\subsubsection{Env iron mental Savings}

To determine whether it is environmentally better to recycle than to dispose off residual latex paint in the landfill, the difference between total impact of landfilling the residual paint $\left(\mathrm{EI}_{\mathrm{L}}\right)$ and the impact of the latex paint recycling process $\left(\mathrm{EI}_{\mathrm{RP}}\right)$ was calculated. A lower value of $\mathrm{EI}_{\mathrm{RP}}$ than $\mathrm{EI}_{\mathrm{L}}$ showed that it is better to recycle than to landfill the paint. This calculation was done for each impact category. The results of the environmental costs and benefits calculation are in Table 3 . The negative values indicate environ mental benefits.

These results showed that recycling latex paint by the process brings significant savings in global warming and photochemical smog impacts. Moreover, the results also showed that recycling latex paint by the process leads to slight increase in eutrophication impact. 
Israel Dunmade: Recycle or Dispose Off? Lifecycle Environmental Sustainability Assessment of Paint Recycling Process

Table 1. Samples of Inventory data for the paint recycling process

\begin{tabular}{|c|c|c|c|}
\hline Data category & Substances & Unit & Quantity \\
\hline Air Emission & Ethane, 1,2-dichloro-1,1,2,2-tetrafluoro-, CFC-114 & $\mathrm{mg}$ & 62.422246 \\
\hline Air Emission & Ethane, dichloro- & $\mathrm{mg}$ & 16.916128 \\
\hline Air Emission & Ethane, hexafluoro-, HFC-116 & $\mathrm{mg}$ & 105.33392 \\
\hline Air Emission & Ethanol & $\mathrm{mg}$ & 457.85147 \\
\hline Air Emission & Ethene, chloro- & $\mathrm{mg}$ & 2.755309 \\
\hline Air Emission & Ethyne & $\mathrm{mg}$ & 97.778655 \\
\hline Air Emission & Methane, bromotrifluoro-, Halon 1301 & $\mathrm{mg}$ & 402.67409 \\
\hline Air Emission & Methane, dichloro-, HCC-30 & $\mathrm{mg}$ & 1.5286144 \\
\hline Air Emission & Methane, tetrachloro-, CFC-10 & $\mathrm{mg}$ & 4.2406896 \\
\hline Air Emission & Methane, tetrafluoro-, FC-14 & $\mathrm{mg}$ & 948.00532 \\
\hline Air Emission & Methane, trichlorofluoro-, CFC-1 1 & $\mathrm{mg}$ & 2.3633944 \\
\hline Air Emission & Methanol & $\mathrm{mg}$ & 554.26237 \\
\hline Air Emission & Acetic acid & g & 1.0406542 \\
\hline Air Emission & Benzene & g & 39.607146 \\
\hline Air Emission & Benzene, ethyl- & $\mathrm{g}$ & 2.2740594 \\
\hline Air Emission & Butane & $\mathrm{g}$ & 78.048095 \\
\hline Air Emission & Butene & g & 25.573004 \\
\hline Air Emission & Dinitrogen monoxide & $\mathrm{g}$ & 335.09789 \\
\hline Air Emission & Ethane & $\mathrm{g}$ & 23.853359 \\
\hline Air Emission & Ethene & $\mathrm{g}$ & 775.88079 \\
\hline Air Emission & Formaldehyde & g & 1.838449 \\
\hline Air Emission & Heptane & $\mathrm{g}$ & 17.961586 \\
\hline Air Emission & Hexane & $\mathrm{g}$ & 37.782941 \\
\hline Air Emission & Methane & $\mathrm{kg}$ & 5.6203882 \\
\hline Air Emission & Nitrogen oxides & $\mathrm{kg}$ & 32.189457 \\
\hline Air Emission & Sulfur oxides & $\mathrm{kg}$ & 7.8781966 \\
\hline Raw materials & Baryte, in ground & $\mathrm{kg}$ & 4.5590617 \\
\hline Raw materials & Bauxite, in ground & $\mathrm{kg}$ & 9.690721 \\
\hline Raw materials & Clay, bentonite, in ground & $\mathrm{kg}$ & 1.3143554 \\
\hline Raw mat erials & Clay, unspecified, in ground & $\mathrm{kg}$ & 19.773079 \\
\hline Raw materials & Coal, $18 \mathrm{MJ}$ per kg, in ground & $\mathrm{kg}$ & 193.12426 \\
\hline Raw materials & Coal, brown, $8 \mathrm{MJ}$ per $\mathrm{kg}$, in ground & $\mathrm{kg}$ & 107.61832 \\
\hline Raw materials & Gas, mine, off-gas, process, coal mining/kg & $\mathrm{kg}$ & 1.4600093 \\
\hline Raw materials & Iron, in ground & $\mathrm{kg}$ & 97.440142 \\
\hline Raw materials & Lead, in ground & $\mathrm{kg}$ & 3.0827645 \\
\hline Raw mat erials & Marl, in ground & $\mathrm{kg}$ & 105.16653 \\
\hline Raw materials & Sand, unspecified, in ground & $\mathrm{kg}$ & 2.8753678 \\
\hline Raw materials & Sodium chloride, in ground & $\mathrm{kg}$ & 41.46825 \\
\hline Raw materials & Wood, dry matter & $\mathrm{kg}$ & 9.5688289 \\
\hline
\end{tabular}


Table 2. Contribution of each process lifecycle stage to different impact cat egory

\begin{tabular}{|c|c|c|c|c|}
\hline Process Lifecycle Stages & \multicolumn{4}{|c|}{ Environmental Impact Categories } \\
\hline & $\begin{array}{c}\text { Global Warming } \\
(\mathrm{GWP}) \\
\mathrm{kg} \mathrm{CO}-\mathrm{eq}\end{array}$ & $\begin{array}{c}\text { Ozone Depletion } \\
\text { (ODP) } \\
\mathrm{kg} \mathrm{CFC} \mathrm{11-eq}\end{array}$ & $\begin{array}{c}\text { Photochemical Smog } \\
\text { (POCP) } \\
\mathrm{kg} \mathrm{C}_{2} \mathrm{H}_{4}-\mathrm{eq}\end{array}$ & $\begin{array}{c}\text { Eutrophication } \\
(\mathrm{EP}) \\
\mathrm{max} \mathrm{kg} \mathrm{O}_{2}-\mathrm{eq}\end{array}$ \\
\hline Old paint transfer & 13952.4 & 0.00504 & 1.0334 & 198.151 \\
\hline $\begin{array}{c}\text { Sorting/ } \\
\text { inspection }\end{array}$ & 6402.7 & 0.00939 & 20.2009 & 52.46 \\
\hline High speed mixing & 1220.9 & 0.00021 & 0.02711 & 7.90668 \\
\hline Filtration & 732.5 & 0.00013 & 0.01627 & 4.74401 \\
\hline In-storage tank mixing & 87.708 & $1.60 \mathrm{E}-05$ & 0.00203 & 0.59324 \\
\hline Packag-ing & 16444.5 & 0.02751 & 59.8931 & 141.647 \\
\hline Distri-bution & 62772.9 & 0.02320 & 4.75451 & 907.159 \\
\hline Disposal & 21147.2 & 0.01239 & 20.9182 & 168.956 \\
\hline Gross env. impacts of the process & 122760.7 & 0.07789 & 106.846 & 1481.62 \\
\hline
\end{tabular}

Table 3. Monthly environmental savings from the recycling process

\begin{tabular}{|c|c|c|c|c|}
\hline \multirow[t]{2}{*}{ Process Lifecycle Stages } & \multicolumn{4}{|c|}{ En vi ronmental Impact Categories } \\
\hline & $\begin{array}{l}\mathrm{GWP} \\
\mathrm{kg} \mathrm{CO}_{2} \text {-eq }\end{array}$ & $\begin{array}{l}\text { ODP } \\
\mathrm{kg} \mathrm{CFC} \mathrm{11-eq}\end{array}$ & $\begin{array}{l}\text { POCP } \\
\mathrm{kg} \mathrm{C}_{2} \mathrm{H}_{4} \text {-eq }\end{array}$ & $\begin{array}{c}\mathrm{EP} \\
\max \mathrm{kg} \mathrm{O}_{2}-\mathrm{eq}\end{array}$ \\
\hline Env. impacts of the process (excluding packag'g \& distrib'n) & 22396.2 & 0.01479 & 21.2797 & 263.86 \\
\hline Monthly env. savings from metal \& plastic recycling & $-31,113.48$ & -0.0232 & -16.44 & -184.78 \\
\hline $\begin{array}{l}\text { Monthly env. savings from latex paint recycling instead of } \\
\text { disposal }\end{array}$ & -61.905 & $-5.02 \mathrm{E}-05$ & -2963.6 & -6.5267 \\
\hline $\begin{array}{c}\text { Monthly env. savings from latex paint recycling instead of } \\
\text { producing virgin paint }\end{array}$ & -61.905 & $-5.02 \mathrm{E}-05$ & -2963.6 & -6.5266 \\
\hline $\begin{array}{c}\text { Total env. savings by avoiding landfill disposal, avoiding } \\
\text { producing equivalent amount of virgin paint and carrying out } \\
\text { container recycling }\end{array}$ & -31237.3 & -0.02 & $-5,943.6$ & -197.83 \\
\hline Net monthly env. benefits of paint recycling & $-8,841.1$ & -0.01 & $-5,922.3$ & 66.02 \\
\hline
\end{tabular}

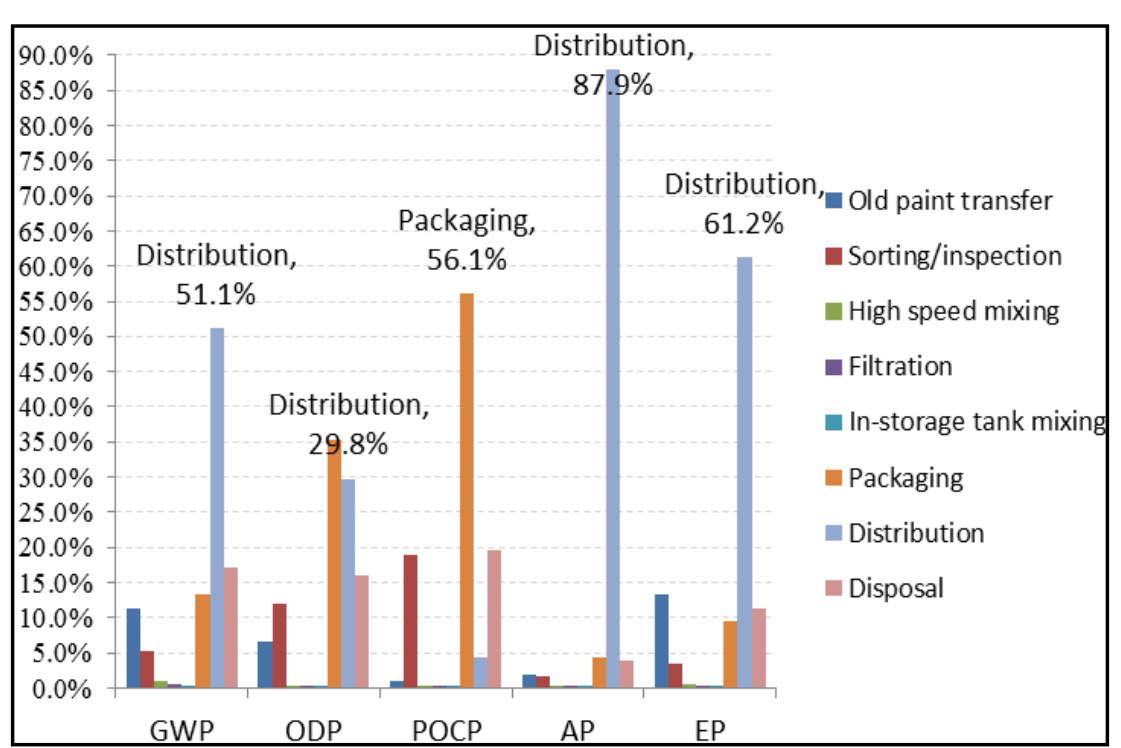

Figure 3. Percentage contribution of each process stage to individual environmental impact

\section{Conclusions}

Considering various stages of the process across the four impact categories shown in Table 2, there is no one single process stage that have the most significant impact across the board. Packaging, distribution and disposal process stages are the three stages that require more urgent attention. This conclusion was based on the significance of their 
impact potentials in most of the impact categories. Recommended improvements for this process are reuse of recycled paint packag ing containers, exp loration of possible alternative onsite use of old paint fraction that is disposed off in the landfill, and alternative transportation method for the distribution of the recycled paint. Results of this work showed that paint recycling process has appreciable global warming potential which could cause climate change. Furthermore, it showed that paint recycling is not only economically wise but it is also ecologically beneficial. Recycling old paint has lower ecological footprint than sending old paint to the landfill for disposal and producing the same amount of virgin paint in replacement.

\section{REFERENCES}

[1] Online available:http://infohouse.p2ric.org/ref/29/28307.pdf.

[2] Online available:http://www.albertarecy cling.ca/BasicConte nt.asp x?id=732.

[3] Online available:http://digitalcommons.library.unlv.edu/cgi/ viewcontent.cgi article $=2232 \&$ context $=$ thesesdissertations.

[4] M. Agocs, R. Etzel, G. Parrish, D. Paschal, P. Campagna, D. Cohen, E. Kilbourne, and J. Hesse, "Mercury Exposure from Interior Latex Paint", Massachusetts Medical Society, The New England Journal of Medicine, vol. 323, pp. 1096-1101, 1990.

[5] R. Reiss, B. Ryan, P. Koutrakis and S. Tibbetts., "Ozone Reactive Chemistry on Interior Latex Paint", ACS Publications, Environmental Science \& Technology, vol. 29, no. 8, pp. 1906-1912, 1995.

[6] L. Sparks, Z. Guo, J. Chang, and B. Tichenor, "Volatile Organic Compound Emissions from Latex Paint - Part 1. Chamber Experiments and Source Model Development", Wiley-Blackwell Publications, Indoor Air (International journal of Indoor Environment and Health), vol. 9, no. 1, pp. 10-17, 1999.

[7] L. Sparks, Z. Guo, J. Chang, and B. Tichenor, "Volatile Organic Compound Emissions from Latex Paint - Part 2. Test House Studies and Indoor Air Quality (IAQ) Modeling", Wiley-Blackwell Publications, Indoor Air (International journal of Indoor Environment and Health), vol. 9, no. 1, pp. 18-25, 1999.
[8] M. Nehdi and J. Summer, "Recycling waste latex paint in concrete. Elsevier publishers, Cement and Concrete research, vol. 33, no. 6, pp. 857-863, 2003.

[9] Walpole, D., "Recycling paint and solvents and reducing use of 1,1,1-trichloroethane", Waste Management, vol. 13, no.2, pp 195-197, 1993

[10] A Mohammed, M Nehdi, and A Adawi, "Recycling waste latex paint in concrete with added value", ACI Materials Journal, 2008

[11] M. Musick, "Old Paint learns new tricks", JG Press Inc, BioCycle, Vol. 32, No. 5, pp. 50-51, 2009.

[12] Daniel, S.; Pappis, C. and Voutsinas, T. (2003). Applying life cycle inventory to reverse supply chains: a case study of lead recovery from batteries. Resources, Conservation and Recycling 37 (2003) 251-/281.

[13] Online available: www.athenasmi.org/resources/research-pro jects.

[14] Online available:http://ec.europa.eu/enterprise/sectors/chemi cals/files/sustdev/pvc-final_report_lca_en.pdf.

[15] F. Berkhout and R. Howes, "The adoption of life-cycle approaches by industry: patterns and impacts", Elsevier publisher, Resources, Conservation and Recycling, vol 20, no. 2, pp. 71-94, 1997.

[16] Tom Chilton, Stephen Burnley, and Suresh Nesaratnam, "A life cycle assessment of the closed-loop recycling and thermal recovery of post-consumer PET", Elsevier publisher, Resources, Conservation and Recycling, vol. 54, no. 12, pp. 1241-1249, 2010.

[17] Online available: www.ellipsos.ca/.../Christmas $\% 20$ Tree $\% 2$ 0LCA \%20-\%20 ellipsos.pdf.

[18] Online available:http://www.eea.europa.eu/publications/GH07-97-595-EN-C.

[19] Katherine Yuracko, Stanton Hadley, Robert Perlack, Rafael Rivera, and Randall Curlee, "Fernald's dilemma: Recycle the radioactively contaminated scrap metal, or bury it?" Elsevier publishers, Resources, Conservation and Recycling, vol. 19, no. 3, pp. 187-198, 1997.

[20] Online available: http://www.thefuturebuild.com/product-lif e-cycle-assessment-981475/file-files/DC8_JotunPaints_Prod uctCarbonFootprint FINAL for\%20Masdar.pdf

[21] Online available:http://www.sveff.se/Branschinformation/L CA_eng.pdf 